\title{
AGAMA DAN ETNISITAS DALAM PEMILIHAN KEPALA DAERAH DI PROVINSI BENGKULU 2015
}

\author{
Ifansyah Putra \\ Universitas Islam Negeri Sunan Kalijaga Yogyakarta \\ Jl. Bima Sakti No.1, RW.02, Demangan, Gondokusuman, Kota Yogyakarta 55221 \\ Email: ifansyahpasker31@gmail.com
}

\begin{abstract}
This study aims to explain the role of religion and ethnicity in winning political actors in the Bengkulu provincial elections, and the effectiveness of the role of religion and ethnicity in winning the candidate. Using political marketing theory, religion and ethnicity are packed into the backdrop of winning political actors. The positioning attitude and branding strategy that is right and mature, raises the political image in getting the sympathy of the community. The result of the research shows that first, the victory of Ridwan Mukti and Rohidin Mersyah have several factors, namely to do the right strategy positioning (candidate compactness, academic degree, mission vision and work program priority, politics politics, cultural preservation, not compartmentalization, harmonization of political elite, and uphold togetherness). Second, religion and ethnicity still as a strategy, but not dominant, its use is based only on the integrity of political actors, by packing Ridwan Mukti and Rohidin Mersyah as political actors who have both values. Thirdly, the principle of primordialism has decreased its effectiveness, so that to be used as the main strategy in electoral politics, especially Bengkulu Province Head Election, no longer has a significant impact like the previous year.
\end{abstract}

Keywords: religion, ethnicity, strategy and election of Regional Head

\begin{abstract}
Abstrak: Penelitian ini bertujuan untuk menjelaskan peran agama dan etnisitas dalam memenangkan aktor politik di pemilihan kepala daerah Provinsi Bengkulu, dan efektivitas dari peran agama dan etnisitas dalam memenangkan kandidat. Dengan menggunakan teori marketing politik, agama dan etnisitas dikemas menjadi latar belakang dalam memenangkan aktor politik. Sikap positioning dan strategi branding yang tepat dan matang, menimbulkan image politik dalam mendapatkan simpati masyarakat. Hasil penelitian menunjukan bahwa pertama, kemenangan Ridwan Mukti dan Rohidin Mersyah memiliki beberapa faktor yakni melakukan positioning strategi yang tepat (kekompakan kandidat, gelar akademik, prioritas visi misi dan program kerja, berpolitik santun, melestarikan budaya, tidak mengkotak-kotakkan, harmonisasi elite politik, dan menjunjung kebersamaan)., Kedua, agama dan etnisitas masih sebagai strategi, namun tidak dominan, penggunaannya hanya didasarkan integritas aktor politik, yakni dengan mengemas Ridwan Mukti dan Rohidin Mersyah sebagai aktor politik yang memilki kedua nilai tersebut. Ketiga, asas primordialisme mengalami penurunan efektivitas, sehingga untuk digunakan sebagai strategi utama dalam politik elektoral, khususnya Pemilihan Kepala Daerah Provinsi Bengkulu, tidak lagi berdampak signifikan seperti tahun sebelumnya.
\end{abstract}

Kata Kunci: agama, etnisitas, strategi dan pemilihan Kepala Daerah. 


\section{Pendahuluan}

Indonesia merupakan bangsa yang kaya akan keragaman etnis dan budaya. Namun pasca runtuhnya Orde Baru dan bergulirnya Era Reformasi, benih-benih perpecahan etnis di daerah mulai menyeruak dengan berlatarkan konflik kepentingan. Seiring diberlakukannya Otonomi Daerah, yang mengharuskan setiap daerah mengupayakan pemberdayaan daerah masing-masing, berdampak pada kesenjangan potensi daerah yang kemudian menjadi persoalan krusial yang kerap menyulut konflik kepentingan. Masing-masing etnis menunjukan rivalitasnya untuk mengedepankan kepentingan kelompoknya, baik ekonomi, sosial, budaya maupun politik. ${ }^{1}$

Seperti halnya menurut Nordholt dan van Klinken, peralihan dari era Orde Baru ke era reformasi ini telah mengubah pandangan masyarakat Indonesia tentang identitas etnis dan agama. ${ }^{2}$ Kebangkitan identitas di era Reformasi dimaknai dengan munculnya identitas kedaerahan dan kesadaran politik baru untuk merestrukturisasikan nilai-nilai kearifan lokal atas dasar primordial etnis dan agama.

Kemajemukan yang ada pada bangsa Indonesia ini bahkan sudah menjadi simbol negara dengan semboyan bangsa yaitu Bhinneka Tunggal, baik itu kemajemukan dari etnis maupun agamanya. Secara mayoritas, menurut hasil The World factbook tahun 2015, 85,2\% dari 255.461.700 penduduk Indonesia ${ }^{3}$ adalah pemeluk agama Islam, dan lain dari pada itu adalah pemeluk Protestan (8,9\%), Katolik (3\%), Hindu (1,8\%), Buddha (0,8\%), dan lain-lain $(0,3 \%)^{4}$. Seperti halnya di Bengkulu, yang memiliki 1.884.788 jumlah penduduk. Jumlah agama yang dianut penduduk Provinsi Bengkulu ada enam yaitu Islam (98,24\%), Kristen (0,78\%), Katholik (0,62\%), Hindu $(0,24 \%)$, dan Budha $(0,11 \%)$, sementara pemeluk Konghucu kurang dari 0,01\%. ${ }^{5}$

\footnotetext{
${ }^{1}$ Agus Salim, Stratifikasi Etnis; Kajian Mikro Sosiologis Interaksi Etnis Jawa dan Cina, (Yogyakarta: Tiara Wacana, 2006), h. 1.

${ }^{2}$ Nordholt, Henk Schulte dan Gerry van Klinken, Politik Lokal di Indonesia, (Jakarta: Yayasan Obor Indonesia, 2007), h. 7

${ }^{3}$ Badan Pusat Statistik, Proyeksi Penduduk menurut Provinsi, 2010-2035, 18 Mei 2015.

${ }^{4}$ Central Intelligence Agency, Indonesia - The World Factbook, 1 November 2016.

${ }^{5}$ Badan Pusat Statistik Provinsi Bengkulu, Bengkulu Dalam Angka 2015, (Bengkulu: BPS Provinsi Bengkulu, 2015), h. 70
}

Selain itu juga kemajemukan etnis di Indonesia tersebar di berbagai provinsi di Indonesia, salah satunya adalah tersebar di Provinsi Bengkulu, yang terdapat berbagai macam etnis. Antara lain yang terdiri dari suku Rejang 60,36\%, Jawa 22,31\%, Serawai 17,87\%, Melayu Bengkulu 7,93\%, Lembak 4,95\%, Minangkabau 4,28\%, Sunda 3,01\%, Suku pekal 10\%, dan lain-lain 18,29\%. ${ }^{6}$

Dalam demokrasi aras lokal, terutama pada pemilihan kepala daerah secara langsung dari tahuntahun sebelumnya, telah menunjukan bahwa peran etnisitas sangat mendominasi dan berpengaruh terhadap kandidat dalam menjaring masa untuk memperoleh kekuatan politik dalam mendapatkan dukungan dari masyarakat. Karena dalam konteks politik identitas, etnis menjadi satu kekuatan yang penting untuk meraih kekuasaan.

Berbicara masalah etnis dalam kontekstasi politik lokal, Provinsi Bengkulu sendiri termasuk salah satu wilayah yang masih sangat kental dengan fenomena politik etnis. Fenomena politik etnis ini berdampak dengan terwujudnya penggunaan etnis lokal -yang biasa dikenal dengan putra asli daerah- sebagai etnis pribumi asli dan penggunaan etnis pendatang di Provinsi Bengkulu dalam ranah politik. Bahkan komposisi etnis mayoritas sering digunakan sebagai basis strategi politik yang digunakan oleh elit lokal untuk mendapatkan dukungan suara dalam pilkada di bumi raflesia ini dalam satu dekade terakhir.

Berdasarkan hasil rekapitulasi suara Komisi Pemilihan Umum pada tahun 2005 dalam pemilihan kepala daerah, menetapkan Agusrin M. Najamuddin, S.T yang berasal dari etnis Serawai dan M. Syamlan, Lc dari etnis Jawa sebagai Gubernur dan Wakil Gubernur masa jabatan 2005-2010. Dengan mendapatkan perolehan suara 52.053 atau 54,30\% dari total suara sah sebanyak 96.764 suara. Pasangan ini dicalonkan oleh Partai Keadilan Sejahtera (PKS) dan Partai Bintang Reformasi (PBR).

Setelah masa jabatan Gubernur dan Wakil Gubernur telah berakhir pada tahun 2010, Agusrin M. Najamuddin, S.T mencalonkan diri lagi dalam periode keduanya dengan diusung oleh Partai

${ }^{6}$ Indonesia's Population: Ethnicity and Relegion in a Changing Political Landscape. Institute of Southeast Asian Studies. 2003 
Amanat Nasional (PAN) dan Partai Demokrat (PD). Ia bersama Junaidi Hamsyah yang berasal dari etnis Rejang mengalahkan pasangan calon lainnya dalam Pemilukada Gubernur dalam satu putaran.

Relevan dengan pemaparan di atas, etnis dan agama oleh antropolog Malinowsky (1982) dikatakan sebagai dua entitas yang sampai saat ini, saat dunia menginjak era modern bahkan post modernisme akan menjadi salah satu perekat sekaligus ketegangan, kerengganan antar elemen dalam masyarakat yang paling berdampak. Etnisitas dan agama merupakan dua entitas yang bersifat bagai pedang bermata dua. Membuat integrasi sekaligus membuat disintegrasi antar anggota masyarakat. Terlebih jika etnisitas dan agama dipahami secara sempit (narrow religion and ethnicity) akan dengan mudah mendorong adanya semangat gerakan perlawanan berdasarkan sentimen etnisitas dan agama tertentu. Inilah mengapa di beberapa daerah persoalan etnisitas dan agama masih dikatakan rentan dan menguntungkan. Rentan terkait akan kemungkinan konflik antar etnis. Menguntungkan karena akan membawa dampak pada asosiasiasosiasi dan akomodasi kebudayaan.?

Fenomena Pilkada tidak bisa hanya dilihat sebagai proses elektoral saja, akan tetapi juga merupakan proses politik yang meletakkan demokrasi sebagai asas terhadap perjuangan. Otoritas primordial (agama dan etnis) menjadi alat utama dalam mempengaruhi masyarakat dalam proses politik. Hal ini menjadi salah satu gerbang untuk mengkonstruksi kekuatan para calon kepala daerah untuk membangun imaginasi politik atas nama suku, ras, dan juga agama. Sehingga mampu membangkitkan emosional rakyat dalam memberikan dukungan dengan mengabaikan halhal yang bersifat rasional, karena telah timbulnya rasa sentimental sosial terhadap pasangan calon kepala daerah tersebut.

Etnis mayoritas yang ada di Bengkulu seperti etnis Rejang, Jawa dan Serawai selalu tampil untuk menjadi poros dalam kontestasi politik lokal. Begitu

${ }^{7}$ Zuly Qodir, Involusi Politik Pemekaran, Etnisitas, Dan Agama: Tantangan Reformasi Birokrasi Kasus Maluku Utara, (Jurnal Bina Praja: 2012), 10 Desember 2012, h. 217. juga dengan agama, sebagai partai pengususng yang berbasiskan Islam simbiotik seperti Partai Keadilan Sejahtera (PKS) dan partai nasionalis relegius yakni Partai Kebangkitan Bangsa (PKB). Dua kekuatan yang selalu berjalan secara relevan tersebut merupakan basis kemenangan yang signifikan pada pemilihan kepala daerah Provinsi Bengkulu selama beberapa tahun terakhir.

Namun pada pemilihan kepala daerah yang dilaksanakan di provinsi Bengkulu pada tahun 2015 kemarin, tampaknya tidak begitu berhasil dalam mengkondisikan peran agama dan etnis. Karena jika dilihat dari hasil Keputusan KPU Provinsi Bengkulu Nomor 48/Kpts/KPU-Prov-007/XII/2015 Tahun 2015 tentang Penetapan Rekapitulasi Hasil Penghitungan dan Hasil Pemilihan Gubernur dan Wakil Gubernur Bengkulu Tahun 2015, ${ }^{8}$ menetapkan pasangan calon Gubernur dan Wakil Gubernur dengan nomor urut 1 (satu) yakni Dr. H. Ridwan Mukti, M.H dan Dr. H. Rohidin Mersyah, M.M, dengan perolehan suara sebanyak 517.190 (lima ratus tujuh belas ribu seratus sembilan puluh) suara atau $57,37 \%$ dari total suara menjadi Gubernur dan Wakil Gubernur yang sah.

Dr. H. Ridwan Mukti, M.H yang merupakan tokoh pendatang dari Musi Rawas Sumatera Selatan dan Dr. H. Rohidin Mersyah, M.M dari etnis Serawai yang diusung oleh Partai Amanat Nasional (PAN), Partai Gerindra, Partai Hati Nurani Rakyat (Hanura), Partai Kebangkitan Bangsa (PKB), Partai Keadilan dan Persatuan Indonesia (PKPI), Partai Nasional Demokrat (NasDem), Partai Golkar, dan Partai Persatuan Pembangunan (PPP) yang dapat mengalahkan pasangan calon putra asli daerah yakni Sultan Nadjamudin dari etnis Serawai dan Mujiono dari etnis terbesar ketiga yakni etnis Jawa yang diusung oleh partai Demokrat, Partai Demokrasi Indonesia Perjuangan (PDI-P) dan Partai Keadilan Sejahtera (PKS).

Hal ini menurut penulis, menegaskan bahwa relasi identitas promordial tidak lagi berjalan secara relevan dan signifikan dalam memenangkan pasangan calon. Karena jika dipahami, hanya partai

${ }^{8}$ Berita Acara KPU Nomor : 57/BA/I/2016, Tentang Penetapan Pasangan Calon Gubernur Dan Wakil Gubernur Bengkulu Terpilih Periode 2016 - 2021, Tahun 2015. 
yang berbasiskan agama saja yang masih mampu menjadi wadah sebagai partai pengusung. Tetapi tidak dengan etnis, yang pada kenyataannya belum bisa mengantarkan pasangan calon yang berasal dari etnis mayoritas di provinsi Bengkulu untuk menjadi Gubernur dan Wakil Gubernur. Padahal secara historis setidaknya satu dekade terakhir, relasi agama dan etnis selalu berjalan secara relevan dan menjadi dua basis kekuatan dalam pesta demokrasi tersebut.

Oleh sebab itu berangkat dari penjabaran di atas, penulis merumuskan masalah penelitian antara lain: 1) Bagaimana strategi yang dilakukan Ridwan Mukti dan Rohidin Mersyah terhadap agama dan etnisitas sebagai alat komoditas dalam Pemilihan Kepala Daerah di Provinsi Bengkulu 2015 ?; 2) Bagaimana Branding politik yang dilakukan Ridwan Mukti dan Rohidin Mersyah terhadap agama dan etnisitas dalam Pemilihan Kepala Daerah di Provinsi Bengkulu 2015 ?; 3) Bagaimana signifikansi atau efektivitas agama dan etnisitas sebagai strategi politik dalam Pemilihan Kepala Daerah di Provinsi Bengkulu?

\section{Metode Penelitian}

Jenis penelitian ini berbentuk deskriptif kualitatif yang bersumber penelitian lapangan (Field Research) di provinsi Bengkulu yang didukung oleh literatur yang ada relevansinya dengan permasalahan. Kemudian dengan menggunakan pendekatan fenomenologis, penulis akan menganalisis beberapa peristiwa-peristiwa yang telah usai berkenaan dengan politik agama dan etnis ketika berlangsungnya kampanye calon Gubernur dan Wakil Gubrnur Provinsi Bengkulu 2015 dengan beberapa data yang telah diarsipkan. Pengumpulan data dilakukan melalui; wawancara mendalam (indepth interview) dan studi dokumentasi berupa arsip penyelenggara pemilukada, berita dan artikel di surat kabar, foto-foto dan barang cetakan yang digunakan sebagai alat peraga yang menunjukkan adanya simbol-simbol dan atribut identitas etnik. Adapun yang menjadi data primer atau responden penelitian ini adalah tim pendukung kandidat pasangan calon Gubernur provinsi Bengkulu 2015. Dan data sekunder diambil berdasarkan literatur yang ada relevansinya dengan permasalahan.

\section{Hasil Penelitian dan Pembahasan}

Relasi agama dan etnisitas masih berpengaruh dalam setiap pesta demokrasi terkhusus pemilihan kepala daerah, begitu juga terhadap pemenangan RM-1, namun peran agama dan etnisitas tersebut tidak lagi menjadi faktor utama sebagai strategi politik yang dilakukan seperti dalam beberapa tahun terakhir. Melainkan terdapat beberapa faktor yang menjadi alasan konstituen dalam menentukan pilihannya, antara lain marketing politik yang dikemas dengan baik, sehingga membentuk image politik yang tertanam dalam ingatan pemilih. Dengan demikian figur RM-1 sendiri menjadi simbolisasi imajinasi sebagai alasan kuat untuk dipilih oleh masyarakat.

Image politik yang berdasarkan agama dan etnisitas hanya menjadi dasar ketika besosialisasi saja, namun untuk mengkampanyekan diri sebagai kandidat yang kuat, digunakan berbagai strategi politik antara lain strategi jaringan, strategi kampanye, dan strategi komunikasi. Oleh karenanya asas primordialisme tidak terlalu diutamakan dalam strategi politik, melainkan hanya sekedar kedekatan antar individu dengan aktor politik tersebut sehingga hubungan emosional tercipta dengan sendirinya.

Agama dan etnisitas hanya berperan sebagai latar belakang aktor politik RM-1. Dari perspektif agama, Ridwan Mukti yang berafiliasi dalam organisasi kemasyarakatan Nahdhatul Ulama, dan Rohidin Mersyah sebagai kader Muhammadiyah. Dan dari etnisitas, Ridwan Mukti berasal dari etnis Rejang dan Rohidin Mersyah sebagai purta Serawai.

Jika masyarakat hanya menilai RM-1 berdasarkan asas primordialisme tersebut, maka RM-1 tidak akan mendapatkan perolehan suara yang besar. Dikarenakan untuk lawan politiknya Sultan B. Najamudin dan Mujiono memiliki kekuatan dalam segi etnisitas. Yakni Sultan B. Najamudin yang berasal dari etnis Serawai dan Mujiono yang berasal dari etnis Jawa hanya mendapatkan perolehan suara yang kecil. ${ }^{9}$

Sedangkan berdasarkan dari hasil perolehan suara, ditiap daerah yang memiliki basis etnisitas

${ }_{9}$ Panji Suminar, Pemerhati Politik, Wawancara pada tanggal 10 Maret 2017. 
seperti Kabupaten Bengkulu Selatan, Kabupaten Kaur, Kabupaten Bengkulu Utara dan Kabupaten Kaur, Sultan Mujiono mengalami kekalahan. Padahal secara historis, Bengkulu yang kental akan kesukuannya menandakan kekuatan etnisitas sebagai basis terhadap dukungan suara.

Dengan demikian, sebagai putra daerah dan etnis mayoritas di Bengkulu menjadikan kekuatan etnisitas terhadap kemenangan, menjadi lemah. ${ }^{10}$ Untuk lebih jelasnya, lihat tabel di bawah ini sebagai bahan acuan pembaca untuk melihat dominasi etnisitas ditiap daerah.

Tabel 1. Klasifikasi Etnis Terhadap Pemenangan ${ }^{11}$

\begin{tabular}{lll}
\hline Daerah & $\begin{array}{l}\text { Dominasi } \\
\text { Etnisitas }\end{array}$ & $\begin{array}{l}\text { Keterangan } \\
\text { (Perolehan Suara) }\end{array}$ \\
\hline Bengkulu Selatan & Serawai & RM-1 Menang : 43.255 \\
\hline Bengkulu Tengah & Rejang dan Lembak & RM-1 Menang : 28.595 \\
\hline Bengkulu Utara & Rejang dan Jawa & RM-1 Menang : 72.196 \\
\hline Kaur & Serawai & RM-1 Menang : 35.129 \\
\hline Kepahiang & Rejang & RM-1 Menang : 38.586 \\
\hline Kota Bengkulu & Lembak, Padang, Serawai & RM-1 Menang : 78.111 \\
\hline dan Jawa & RM-1 Menang : 40.482 \\
\hline Mukomuko & Rejang & Sultan Mujono Menang : 40.940 \\
\hline Rejang Lebong & Rejang & RM-1 Menang : 100.623 \\
\hline Seluma & Serawai & Sultan Mujiono Menang : 39.272 \\
\hline
\end{tabular}

Berdasarkan perolehan suara yang mendominasi primordialisme sebagai kekuatan politik di atas, menandakan bahwa hanya terdapat dua daerah saja yang dapat memenangkan pasangan Sultan B. Najamudin dan Mujiono yakni Kabupaten Seluma dan Kabupaten Mukomuko. Namun dari suara yang didapat, juga tidak mengindikasikan seseluruhan bahwa Sultan Mujiono memenangkan berdasarkan etnisitas saja, dikarenakan jumlah perolehan suara yang didapat Sultan Mujiono tidak memilki selisih yang signifikan terhadap lawan politiknya RM-1. Padahal di daerah tersebut merupakan sumber dukungan suara berdasarkan segi etnisitas. Dengan

\footnotetext{
${ }^{10}$ Ibid.

${ }^{11}$ Indonesia's Population: Ethnicity and Religion in a Changing Political Landscape. Institute of Southeast Asian Studies. (Singapura: Institut Studi Asia Tenggara) 2003.
}

demikian, dapat dikatakan bahwa kekuatan atas asas primordialisme dalam pemilihan kepala daerah menjadi lemah.

Dengan demikian, marketing politik yang dikemas berdasarkan asas primordialisme memiliki pengaruh yang tidak sekuat dulu. Kemenangan yang didapat oleh RM-1 menjadikan bukti bahwa agama dan etnisitas hanya berlaku ketika difungsikan dengan sebaik mungkin. Oleh sebab itu, RM-1 tidak memprioritaskan agama dan etnisitas sebagai strategi politiknya. Melainkan dengan menggunakan berbagai strategi yang dapat menunjang perolehan suara. ${ }^{12}$

Terdapat faktor lain yang berdampak jauh lebih maksimal, yakni dengan mengemas agama dan etnisitas sebagai dasar dari strategi politiknya. Marketing poltik disini lebih berperan, dengan mem posisikan diri sebagai agamawan dan pribumi, melahirkan brand politik yang jauh lebih maksimal. Dikarenakan image yang telah dibangun akan terus melekat dalam ingatan masyarakat sebagai pemilih. Untuk lebih jelasnya lihat pada tabel di bawah ini.

\begin{tabular}{lll}
\hline Strategi & Objek Strategi & Dampak yang diberikan \\
\hline \multirow{2}{*}{$\begin{array}{l}\text { Kekompakan dalam foto } \\
\text { kandidat }\end{array}$} & $\begin{array}{l}\text { Kuat, mencerminkan RM-1 dapat } \\
\text { bekerja sama dengan wakilnya }\end{array}$ \\
\cline { 2 - 3 } Gelar akademik & $\begin{array}{l}\text { Kuat, menandakan RM-1 memilki } \\
\text { ilmu pengetahuan dalam } \\
\text { membangun Provinsi }\end{array}$ \\
\cline { 2 - 3 } yang jelas & $\begin{array}{l}\text { Prioritas visi misi dan } \\
\text { program kerja }\end{array}$ & $\begin{array}{l}\text { Kuat, sesuai yang dibutuhkan oleh } \\
\text { masyarakat }\end{array}$ \\
\cline { 2 - 3 } & Berpolitik santun & $\begin{array}{l}\text { Kuat, mengindikasikan RM-1 sebagai } \\
\text { kompetitor yang profesional }\end{array}$ \\
\cline { 2 - 3 } & Melestarikan budaya & $\begin{array}{l}\text { Kuat, menandakan RM-1 mencintai } \\
\text { budaya leluhur }\end{array}$ \\
\cline { 2 - 3 } & $\begin{array}{l}\text { Tidak mengkotak- } \\
\text { kotakan }\end{array}$ & $\begin{array}{l}\text { Kuat, meninggalkan asas } \\
\text { primordialisme }\end{array}$ \\
\cline { 2 - 3 } $\begin{array}{l}\text { Harmonisasi elite politik } \\
\text { branding }\end{array}$ & $\begin{array}{l}\text { Kuat, relasi yang dibangun akan } \\
\text { berdampak pada pemerataan }\end{array}$ \\
\hline & $\begin{array}{l}\text { Rekomendasi dan } \\
\text { dukungan, }\end{array}$ & $\begin{array}{l}\text { Kuat, dengan slogan "Maju Bersama } \\
\text { Harapan Rakyat" }\end{array}$ \\
\cline { 2 - 3 } & $\begin{array}{l}\text { Kemampuan : } \\
\text { Nasionalis,akademis, } \\
\text { agamis, berpengalaman dengan tokoh-tokoh } \\
\text { dan cerdas dalam } \\
\text { memecahkan masalah }\end{array}$ & $\begin{array}{l}\text { Kuat, berdampak pada figur yang } \\
\text { dinginkan masyarakat }\end{array}$ \\
\cline { 2 - 3 } & $\begin{array}{l}\text { Menjunjung } \\
\text { kebersamaan }\end{array}$ & \\
\hline
\end{tabular}

${ }^{12}$ Herliardo, DPW PKB Bengkulu, Wawancara pada tanggal 21 Februari 2017. 


\begin{tabular}{lll}
\hline & Prilaku : & Kuat, masyarakat lebih menyukai \\
& Mewakafkan diri, rendah & figur yang berkarakter \\
hati, sopan santun, & \\
menjalin komunikasi, & \\
responsif, humanis, & \\
kharismatik, dan & \\
kekerabatan, & \\
\cline { 2 - 3 } & Metode : & Kuat, mudah dingat dan melekat di \\
& "Maju Bersama Harapan & masyarakat \\
& Rakyat" & \\
& "Menuju Bengkulu Baru" & \\
& "RM-1" & \\
& track record RM-1 & \\
\hline Konstruksi & Menampilkan sosok RM-1 & Berhasil dalam mengambil simpati \\
image & sebagai figur seorang & masyarakat \\
& pemimpin & \\
\hline
\end{tabular}

Keterangan : Diolah berdasarkan Positioning dan Branding RM-1 pada bab sebelumnya.

Sentimen primordial atau primordialisme adalah pandangan atau paham yang memegang teguh hal-hal yang dibawa sejak kecil, baik mengenai tradisi, adat istiadat, kepercayaan, maupun segala sesuatu yang ada di dalam lingkungan pertamanya. Primordialisme adalah perasaan kesukuan yang berlebihan. Bentuk sentimen primordial ini seringkali dijadikan strategi politik oleh aktor politik terutama saat waktu menjelang pemilihan kepala daerah.

Jika dilihat dari segi politik saat ini, menjelang pemilihan kepala daerah, sentimen primordial memang memiliki beberapa keuntungan dan kerugian. Dengan sentimen primordial, pemimpin yang dipilih jelas sudah mengenal betul kondisi dan keadaan daerah tersebut. Tetapi asas primordialisme ini juga memilki kerugian yang berdampak besar pada perolehan hasil suara yang berkurang.

Oleh sebab itu, pada masa sekarang ini, akan lebih baik menggunakan strategi-strategi politik lainnya dalam mandapatkan dukungan suara. Dikarenakan masyarakat telah mengalami perubahan, masyarakat telah mempelajari bahwa seorang pemimpin adalah orang yang mampu mensejahterakan masyarakat nya, yang terlihat pada kapasitas individu seorang pemimpin, baik itu dari dari visi misi, program, hingga sosok pemimpin tersebut layak untuk dijadikan figur. ${ }^{13}$

Dengan dikampanyekannya visi dan misi seorang kandidat, masyarakat akan menilai dengan

13 Rohidin Mersyah, Pelaksana Tugas Gubernur Bengkulu, Wawancara pada tanggal 21 Maret 2017. sendirinya, mana yang lebih baik diterapkan dalam membangun suatu provinsi. Terlebih lagi dengan melihat fakta-fakta yang ada di lapangan, membuat tim relawan dan pendukung untuk lebih lagi menemukan apa yang menjadi kebutuhan pemilih sehingga brand yang dibangun akan sampai pada masyarakat.

Fakta yang ada dalam organisasi sendiri, yakni aktor politik yang memiliki integritas dan mempunyai daya tarik tersendiri akan menjadikan sumber utama dalam pemenangan. Sehingga dalam penilaian masyarakat sekitar bahwa untuk seorang pemimpin harus memiliki sikap yang jelas (positioning) dan dilatarbelakangi oleh brand yag baik. Yang pada akhirnya akan menanamkan image sebagai imajinasi simbolisasi terhadap pemilih. ${ }^{14}$

Salah satu budayawan Bengkulu sekaligus dosen salah satu Universitas yang ada di Bengkulu Agus Setiyanto ${ }^{15}$ menyebutkan bahwa, untuk menjadi figur di masyarakat harus memilki sifat yang responsif, kepekaan yang tinggi, humanis, memiliki kharismatik atau daya pikat, dan juga melakukan strategi sikap politik yang menyentuh seperti yang dimilki oleh RM-1.

Agus menambahkan juga bahwa terjadi hal yang berbeda dengan lawannya Sultan B. Najamudin dan Mujiono, yang terlalu yakin akan dirinya, tidak responsif, frontal, bahkan lebih condong bersifat menyerang ketika melakukan strategi kampanyenya dan juga salah dalam memilih wakilnya yakni Mujiono. Bahkan dalam wawancaranya menyebutkan, Ridwan Mukti melakukan pendekatan yang bersifat persuasif, yakni dengan "Ketok Pintu" atau silaturahmi langsung kepada tokoh-tokoh yang berpengaruh di Provinsi Bengkulu. Hal ini yang menjadi alasan masyarakat Bengkulu dalam menentukan pilihanya, dikarenakan kedua tokoh tersebut sangat tampak akan perbedaannya.

Selanjutnya sebagai pemerhati politik di Provinsi Bengkulu, sekaligus akademisi sosial politik di salah satu Universitas yang ada di Bengkulu, Dr. Panji

${ }^{14}$ M.Sis Rahman, Politisi Gerindra, Wawancara pada tanggal 05 Maret 2017.

15 Agus Setiyanto, Budayawan Bengkulu, Wawancara pada tangga 19 Februari 2017. 
Suminar. ${ }^{16}$ Menyebutkan bahwa sejak tahun 2014 Ridwan Mukti mampu meyakinkan masyarakat sebagai sosok figur, dengan mensosialisasikan rekam jejaknya ketika memimpin Kabupaten Musi Rawas dan karir politiknya selama ini.

Selain itu juga Panji Suminar menyebutkan aktor politik harus merupakan produk yang bagus, terlebih lagi kemasan yang bagus akan menaikan harga jual yang tinggi terhadap masyarakat sebagai pemilih. Salah satu ciri produk yang bagus dalam politik yakni dengan mengedepankan asas kekerabatan yang terjalin, sehingga masyarakat akan menerima dengan mudah, hal ini yang dimilki oleh Ridwan Mukti dan Rohidin Mersyah.

Ditambahkan juga oleh Panji bahwa berdasarkan rekam jejak yang selama ini RM-1 bangun, memudahkan untuk menyampaikan gagasan dengan baik apalagi ketika gagasan tersebut dibutuhkan oleh masyarakat. Secara tidak langsung RM-1 juga mengkampanyekan sesuatu yang terhindar dari isu putra daerah, padahal Ridwan Mukti dan Rohidin Mersyah masing-masing memilki garis keturunan asli sebagai etnis Provinsi Bengkulu.

Hal yang diinginkan oleh masyarakat seperti kebutuhan pendidikan, ekonomi dan infrastruktur yang memadai menjadi prioritas dalam mensosialisasikan diri sebagai aktor politik yang memperhatikan masyarakat. Sehingga figur Ridwan Mukti dan Rohidin Mersyah saling melengkapai dalam hal mengkampanyekan diri sebagai pemimpin yang baru.

Terlebih lagi jika dilihat berdasarkan keaktifan Ridwan Mukti dan Rohidin Mersyah dalam organisasi kemasyarakatan seperti NU dan Muhammadiyah. Ridwan Mukti adalah NU, dan Rohidin Mersyah adalah Muhammadiyah, oleh sebab itu, sebagai kader yang loyalitas tinggi kedua tokoh ini akan saling melengkapi.

Selain itu juga, RM-1 memilki tim yang berkompeten dalam melakukan strategi politik nya, adanya tim fungsional seperti kerabat yang memiliki posisi di birokrasi, tim partai yang menjadi pengusung, tim struktural yang memiliki tugas

${ }^{16}$ Panji Suminar, Pemerhati Politik, Wawancara pada tanggal 10 Maret 2017. dan fungsi masing-masing, dan yang terakhir tim keluarga baik itu keluarga besar Ridwan Mukti maupun keluarga besar Rohidin Mersyah sendiri. ${ }^{17}$

Selanjutnya wawancara dengan Wakil Gubernur terpilih Rohidin Mersyah, menyebutkan bahwa yang menjadi alasan ketika menyanggupi tawaran Ridwan Mukti yakni dikarenakan Ridwan Mukti adalah politikus senior yang telah banyak berkecimpung dalam dunia politik nasional maupun skala lokal. ${ }^{18}$ Sehingga untuk pengalaman Ridwan Mukti dalam memimpin suatu daerah tidak diragukan lagi.

Selain itu juga disebutkan bahwa Ridwan Mukti memilki visi yang besar dalam kemajuan Provinsi Bengkulu, dikarenakan selama ini Provinsi Bengkulu merupakan daerah yang tertinggal, bahkan memilki wilayah-wilayah di dalamnya termasuk daerah miskin dan kurang mampu. Dapat dilihat berdasarkan visi misi dan program kerja yang Ridwan Mukti tawarkan, dianggap bisa membawa Bengkulu pada tingkat nasional. Dikarenakan Ridwan Mukti memilki akses dan relasi terhadap aktor politik yang ada di pusat pemerintahan.

Dalam wawancara tersebut dijelaskan juga oleh Rohidin Mersyah bahwa dalam melakukan kampanye, tidak mempersoalkan asas primordialisme, hanya sekedar kekerabatan yang berpengaruh sehingga menimbulkan emosional yang berdampak positif. Dikarenakan Bengkulu memiliki masyarakat yang bersifat heterogen, sehingga tidak bisa hanya fokus untuk membahas satu etnisitas saja.

Dijelaskan juga oleh Rohidin Mersyah bahwa alasan utama yang memenangkan RM-1 adalah kekuatan figur atas dasar kapasitas dalam kelayakan menjadi pemimpin. Dapat dilihat ketika debat kandidat berlangsung, ketika Sultan B. Najamudin dan Mujiono lebih mengkampanyekan dirinya sebagia putra asli daerah, sedangkan RM-1 lebih pada mengkampanyekan visi misi dan program kerja nya. ${ }^{19}$

Pada strategi kampanye yang dilakukan oleh

\footnotetext{
${ }^{17}$ Ibid.

${ }^{18}$ Rohidin Mersyah, Wagub Bengkulu, Wawancara pada tanggal

${ }^{19}$ Ibid.
} 21 Maret 2017. 
tim pemenangan kanditat Ridwan Muti dan Rohidin Mersyah, positioning dan branding dalam membangun image juga melalui tegnologi informasi dan komunikasi, dikarenakan ini merupakan alat yang berpengaruh kuat dalam mengkampanyekan visi dan misi kandidat. Bahkan dalam strategi tersebut, efek yang diberikan bukan hanya sekedar memperkenalkan siapa aktor politik tersebut, melainkan juga dapat mengangkat popularitas yang dibungkus dengan nilai-nilai elektabilitas seorang figur.

Konsep iklan politik menurut Lynda Lee Kaid adalah usaha mempromosikan sebuah produk, pelayanan, kandidat maupun gagasan (ide) dalam ruang publik politik melalui media massa. ${ }^{20}$ Selanjutnya dijelaskan oleh Burhan Bungin, pada mulanya kajian iklan, termasuk iklan televisi merupakan sub-kajian studi masyarakat dan komunikasi massa, kemudian bersentuhan dengan studi media massa dan sosiologi media serta konstruksi sosial. ${ }^{21}$

Iklan politik telah menjadi fenomena yang mengemuka buah dari keterbukaan politik era reformasi, secara khusus fenomena iklan politik menguat seiring dengan terbukanya kompetisi politik dalam pemilihan umum, termasuk dalam nya pada tingkat daerah. Hal ini yang menjadikan iklan politik seringkali digunakan sebagai media kampanye yang di dalamnya menerapkan komunikasi politik, juga bermakna pencitraan untuk membangun identitas politik masing-masing, menaikan popularitas dan elektabilitas pilihan dari konstituen.

Aktor politik yang menguasai media iklan, akan semakin dikenal oleh masyarakat. Aktor politik yang sering muncul di media akan menjadi perhatian sekaligus sorotan masyarakat. Kemunculannya akan dinantikan oleh masyarakat, oleh karena itu penampilan harus tetap dijaga. Kondisi ini membawa akibat aktor politik harus menjadi tauladan. Kekuatan untuk menjaga moralitas ini merupakan konsekuensi logis dari orang yang menjadi aktor

${ }^{20}$ Lynda Lee Kaid, Political Advertising dalam Handbook of Political Communication Research, (New Jersey, London: LEA Publishers) 2004.

${ }^{21}$ Burha Bungin, Konstruksi Sosial Media Massa: Makna Relaitas Sosial Iklan Televisi dalam Masyarakat Kapitalistik, Desertasi. (Surabaya: Universitas Airlangga, 2000). h. 1. politik yang selalu tampil di muka publik.

Pada kasus ini, Ridwan Mukti dan Rohidin Mersyah sebagai aktor politik menggunakan iklan politik sebagai simbolisasi figus yang memiliki kedua nilai (agama dan etnisitas) tersebut, sehingga framing yang dibangun akan berdampak pada besarnya dukungan dari masyarakat. Agama dan etnisitas tidak dijadikan sumber kekuatan seperti yang dilakukan oleh lawan politiknya Sultan Mujiono. Dengan menggunakan cara yang berbeda, Ridwan Mukti dan Rohidin Mersyah lebih menitikberatkan pada konsep marketing politik untuk mempubikasikan bahwa sebagai figur yang siap menjadi pemimpin provinsi Bengkulu.

Agama dan etnisitas bukan lagi menjadi faktor utama dalam kemenangan Ridwan Mukti dan Rohidin Mersyah, melainkan hanya menjadi faktor pendukung dalam melihat segmentasi politik masyarakat Bengkulu. Isu putra daerah dan juga agamawan hanya dilihat berdasarkan kedekatan dengan tokoh-tokoh saja, tidak dijadikan landasan dari masyarakat untuk memilih. Dengan demikian terjadinya perubahan fungsi kekuatan agama dan etnisitas dalam ranah politik lokal tersebut, yang dahulunya dijadikan alasan kuat untuk menentukan pilihan, sekarang lebih mentikberatkan pada produk dari marketing politik tersebut. ${ }^{22}$

Sehingga dengan perubahan tersebut, kemasan terhadap agama dan etnisitas juga mengalami perubahan. Hal ini yang penulis maksud dengan devitalisasi terhadap agama dan etnisitas, oleh sebab itu dalam strategi politik agama dan etnisitas hanya digunakan sebagai faktor kedekatan dalam mendapatkan dukungan, bukan lagi secara frontal yang dengan mencari dukungan berdasarkan agama yang sama dan etnis yang mendominasi dalam perebutan suara pemilih.

Dalam konsep ashabiyah Ibn Khaldun menyebutkan bahwa masyarakat yang memiliki sentimental emosional terhadap tokoh atau disini aktor politik, akan lebih memilih untuk mendukung apa saja yang berhubungan dengan ikatan darah, ikatan keluarga, rasa solidaritas kesukuan dan

${ }^{22}$ Rizkan A. Rahman, Katib Suryah PWNU Bengkulu, Wawancara 2 Maret 2017. 
juga kesamaan dalam tujuan tersebut. Hal ini yang masih dugunakan Sultan Mujiono dalam mencari dukungan suara politiknya. Sebaliknya Ridwan Mukti dan Rohidin Mersyah lebih fokus untuk mengkampanyekan visi misi dan program kerjanya sebagai pemimpin Bengkulu kedepannya.

Pada dasarnya, agama dan etnisitas tidak bisa dipisahkan dalam mencari dukungan suara konstituen, namun pada kasus ini hal tersebut bukan menjadi strategi utama dalam mendapatkan dukungan. Sehingga keradikalisasian terhadap agama dan etnisitas mengalami perubahan, tidak dilakukannya strategi politik dengan mengatasnamakan agama dan etnisitas secara terangterangan, melainkan hanya sekedar memiliki hubungan yang berdasarkan agama dan etnisitas tersebut. Sehingga masyarakat Bengkulu secara tidak langsung akan memilih sebuah produk politik berdasarkan nilai-nilai rasional, yang menjunjung tinggi kompetisi yang sehat dan bersih, tanpa adanya isu-isu yang mengatasnamakan primordialisme yakni agama dan etnisitas.

\section{Penutup}

Dari beberapa uraian di atas, penulis menarik kesimpulan bahwa dalam masa kampanye hingga terpilihnya Ridwan Mukti dan Rohidin Mersyah sebagai Gubernur dan Wakil Gubernur Provinsi Bengkulu terdapat banyak hal yang menjadikan faktor kemenangan tersebut antara lain adalah pengkonsepan yang matang terhadap marketing politik yang di dalamnya terdapat positioning strategi, branding strategi, strategi jaringan dan komunikasi, hingga pada akhirnya kuasa agama dan etnisitas akan dengan mudah juga beroperasi.

Oleh sebab itu, penulis juga menyatakan bahwa dari segi wawasan dalam informasi, masyarakat Bengkulu khususnya telah mengalami peningkatan dalam pengkonsumsiannya terhadap politik. Sehingga masyarakat mengalami kesadaran politik atau istilah yang sering berkembang adalah melek politik.

Dengan kemenangan yang didapatkan oleh pasangan Ridwan Mukti dan Rohidin Mersyah, menyatakan bahwa asas primordial (Agama dan Etnisitas) tidak dapat digunakan atau diimplementasikan lagi sebagai startegi utama dalam ruang lingkup politik elektoral khusunya Pemilihan Kepala Daerah Provinsi Bengkulu. Masyarakat mengalami pendewasaan dalam bidang politik, dengan positioning yang jelas akan melahirkan brand yang memikat, sehingga image politik seorang aktor politik akan tertanam dalam masyarakat ketika menentukan pilihannya.

\section{Pustaka Acuan}

Badan Pusat Statistik Provinsi Bengkulu, Bengkulu Dalam Angka 2015, (Bengkulu: BPS Provinsi Bengkulu, 2015)

Badan Pusat Statistik, Proyeksi Penduduk menurut Provinsi, 2010-2035, 18 Mei 2015.

Berita Acara KPU Nomor : 57/BA/I/2016, Tentang Penetapan Pasangan Calon Gubernur Dan Wakil Gubernur Bengkulu Terpilih Periode 2016 -2021, Tahun 2015.

Bungin, Burhan, Konstruksi Sosial Media Massa: Makna Relaitas Sosial Iklan Televisi dalam Masyarakat Kapitalistik, Desertasi. (Surabaya: Universitas Airlangga, 2000).

Central Intelligence Agency, Indonesia - The World Factbook, 1 November 2016.

Herliardo, DPW PKB Bengkulu, Wawancara pada tanggal 21 Februari 2017.

Indonesia's Population: Ethnicity and Relegion in a Changing Political Landscape. Institute of Southeast Asian Studies. 2003

Indonesia's Population: Ethnicity and Religion in a Changing Political Landscape. Institute of Southeast Asian Studies. (Singapura: Institut Studi Asia Tenggara) 2003.

Kaid, Lynda Lee, Political Advertising dalam Handbook of Political Communication Research, (New Jersey, London: LEA Publishers) 2004.

Mersyah, Rohidin, Pelaksana Tugas Gubernur Bengkulu, Wawancara pada tanggal 21 Maret 2017.

Nordholt, Henk Schulte dan Gerry van Klinken, Politik Lokal di Indonesia, Jakarta: Yayasan Obor Indonesia, 2007. 
Qodir, Zuly, Involusi Politik Pemekaran, Etnisitas, Dan Agama: Tantangan Reformasi Birokrasi Kasus Maluku Utara, (Jurnal Bina Praja: 2012), 10 Desember 2012

Rahman, M.Sis, Politisi Gerindra, Wawancara pada tanggal 05 Maret 2017.

Rahman, Rizkan A., Katib Suryah PWNU Bengkulu, Wawancara 2 Maret 2017
Salim, Agus, Stratifikasi Etnis; Kajian Mikro Sosiologis Interaksi Etnis Jawa dan Cina, Yogyakarta: Tiara Wacana, 2006.

Setiyanto, Agus, Budayawan Bengkulu, Wawancara pada tangga 19 Februari 2017.

Suminar, Panji, Pemerhati Politik, Wawancara pada tanggal 10 Maret 2017. 